\title{
THE
}

1998

\section{Breeding Ecology and Behavior of the Hawaiian Hawk}

Curtis R. Griffin

Peter W. C. Paton

University of Rhode Island, ppaton@uri.edu

Thomas S. Baskett

Follow this and additional works at: https://digitalcommons.uri.edu/nrs_facpubs

Part of the Environmental Sciences Commons, and the Ornithology Commons Terms of Use

All rights reserved under copyright.

\section{Citation/Publisher Attribution}

Griffin, C., Peter W. C. Paton, \& Baskett, T. (1998). Breeding Ecology and Behavior of the Hawaiian Hawk. The Condor, 100(4), 654-662. doi:10.2307/1369746

Available at: http://dx.doi.org/10.2307/1369746

This Article is brought to you for free and open access by the Natural Resources Science at DigitalCommons@URI. It has been accepted for inclusion in Natural Resources Science Faculty Publications by an authorized administrator of DigitalCommons@URI. For more information, please contact digitalcommons-group@uri.edu. 


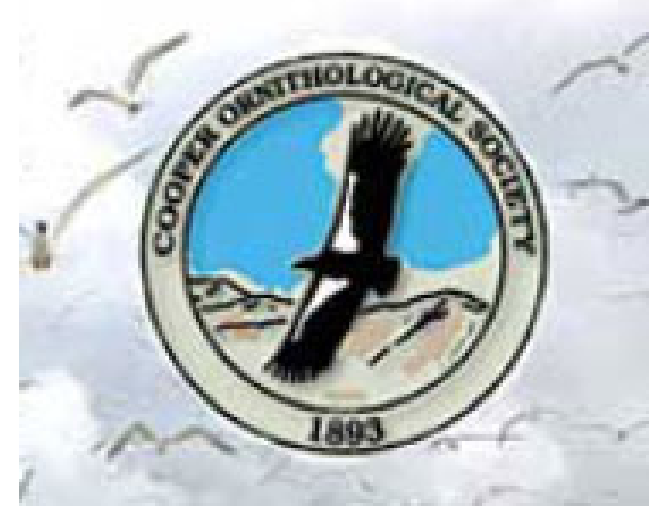

Breeding Ecology and Behavior of the Hawaiian Hawk

Author(s): Curtice R. Griffin, Peter W. C. Paton and Thomas S. Baskett

Reviewed work(s):

Source: The Condor, Vol. 100, No. 4 (Nov., 1998), pp. 654-662

Published by: University of California Press on behalf of the Cooper Ornithological Society

Stable URL: http://www.jstor.org/stable/1369746

Accessed: 16/07/2012 15:11

Your use of the JSTOR archive indicates your acceptance of the Terms \& Conditions of Use, available at http://www.jstor.org/page/info/about/policies/terms.jsp

JSTOR is a not-for-profit service that helps scholars, researchers, and students discover, use, and build upon a wide range of content in a trusted digital archive. We use information technology and tools to increase productivity and facilitate new forms of scholarship. For more information about JSTOR, please contact support@jstor.org.

University of California Press and Cooper Ornithological Society are collaborating with JSTOR to digitize, preserve and extend access to The Condor. 


\title{
BREEDING ECOLOGY AND BEHAVIOR OF THE HAWAIIAN HAWK ${ }^{1}$
}

\author{
Curtice R. Griffin², Peter W. C. Paton ${ }^{3}$ and Thomas S. Baskett \\ School of Forestry, Fisheries, and Wildife, University of Missouri-Columbia, Columbia, MO 65211, \\ e-mail: cgriffin@forwild.umass.edu
}

\begin{abstract}
We studied the ecology of the endangered Hawaiian Hawk (Buteo solitarius) on the island of Hawaii for three breeding seasons. Their breeding strategy is a prime example of a K-selected species characteristic of many birds in tropical environments: clutch size was one and brood-rearing was among the longest reported for any diurnal raptor. Twenty-eight nests were found in a variety of native and exotic habitats. Incubation lasted 38 days, nestlings fledged after 59-63 days, and parents cared for fledglings for an average of 30.2 weeks, which was 2.5 to 10 times longer than similar-size temperate zone raptors. Males assisted females with incubation, but only females brooded young. Radio-tagged juveniles remained within $0.63 \mathrm{~km}$ of their nests for the first two months after fledging, after which dispersal distances expanded gradually. Avian (45\%) and mammalian (54\%) prey dominated the diet of nestlings. There was no evidence that avian malaria, introduced predators, or environmental contaminants were affecting their population. Based upon estimates of population size, the availability of suitable nesting habitat, and reproductive success, we suggest the species be considered for downlisting from endangered to threatened status.
\end{abstract}

Key words: breeding ecology, Buteo solitarius, clutch size, diet, Hawaiian Hawk, nest success.

\section{INTRODUCTION}

The Hawaiian Hawk or 'Io (Buteo solitarius) is a medium-sized, broad-winged buteonine endemic to the Hawaiian Islands. Although this hawk was believed to be threatened with extinction and included on the Endangered Species List in 1967, little was known about its population status or breeding ecology at the time of the listing decision. Information about the distribution, abundance, and biology of the Hawaiian Hawk is anecdotal (Banko 1980), with the exception of systematic surveys by Scott et al. (1986) and Hall et al. (1997). Fossils of Hawaiian Hawks have been found on Hawaii, Molokai, and Kauai (Olson and James 1997), and there have been eight documented observations of the species on the islands of Kauai, Oahu, and Maui since 1778 (Banko 1980, Olson 1990). Since ornithologists have studied the Hawaiian Islands, Hawaiian Hawks have nested only on the island of Hawaii from sea level to $2,600 \mathrm{~m}$

\footnotetext{
${ }^{1}$ Received 5 August 1997. Accepted 13 May 1998.

${ }^{2}$ Current address: Department of Forestry and Wildlife Management and Graduate Program in Organismic and Evolutionary Biology, University of Massachusetts, Holdsworth Hall, Amherst, MA 01003.

${ }^{3}$ Current address: Department of Natural Resources Science, University of Rhode Island, Kingston, RI 02881 .
}

(Banko 1980, Scott et al. 1986). The Hawaiian Hawk is among the most sexually dimorphic of the world's buteonine raptors (Paton et al. 1994). Objectives of the present study were to quantify nesting habitat, breeding behavior and chronology, nest success, diet, and other factors affecting reproduction.

\section{METHODS}

\section{STUDY AREA}

Our fieldwork was conducted on the island of Hawaii, the largest island in the Archipelago, $10,456 \mathrm{~km}^{2}$. It is formed by the major volcanoes of Kilauea, Mauna Loa, Mauna Kea, Hualalai, and Kohala, and comprises about $62 \%$ of the land area of the Hawaiian Islands (Armstrong 1973). Although fieldwork took place throughout the island, observations of nests and telemetry studies were concentrated in the northeastern side of the island (Griffin 1985).

Hawaii Island has the greatest diversity of biogeoclimatic zones in the Archipelago because of its large size and recent origin (Armstrong 1973). As is typical of all Hawaiian islands, much of the native biota is endemic. However, most of these indigenous ecosystems have been modified by competition from introduced plants, overgrazing by introduced ungulates, logging operations, and urban and agricultural develop- 
ment. Agriculture dominated much of Hawaii Island below $700 \mathrm{~m}$ elevation. In 1983, $435 \mathrm{~km}^{2}$ were in sugarcane, $66 \mathrm{~km}^{2}$ were in diverse crops (primarily macadamia nuts, papaya and other fruit crops, and coffee), and $3,223 \mathrm{~km}^{2}$ were in pasture (Hawaii Department of Agriculture, Honolulu, unpubl. data).

All intensive observations of hawks were conducted at low and mid elevations (70-1,740 m) where the landscape is dominated by agricultural lands, exotic vegetation, and disturbed native forests. Hawks were not studied in undisturbed native forests because of difficulty of access. Five nests were observed from blinds including two in tall ohia (Metrosideros polymorpha) forests with mixed native and exotic understory; one in an agricultural area within a tree windrow separating guava and papaya orchards, and two in disturbed pasture grasslands with scattered large koa (Acacia koa) and ohia trees.

\section{FIELD PROCEDURES}

Fieldwork was conducted 5-6 days per week for 19 months from April 1980 through October 1981. Additional fieldwork from October 1981 through July 1982 averaged one day per week, and involved checking nests for activity.

To find active nests, we first relocated 8 of 11 historic nests found from 1973 to 1979 by a number of researchers (Griffin 1985). Island residents also showed us several nests after reading about our study in the local newspaper. We also systematically searched for new nest territories by driving roads in the Puna, Hilo, and North Hilo districts of the island. During these road surveys, we stopped the vehicle at $1.0-\mathrm{km}$ intervals and attempted to attract territorial hawks with playback of an amplified, territorial $\mathrm{Ha}$ waiian Hawk call over a portable bullhorn for 5-10 min (Balding and Dibble 1984). Potential hawk territories were discovered by watching for soaring hawks and listening for their vocalizations. For these reasons, $36 \%$ of nests found were situated within $0.5 \mathrm{~km}$ of primary or secondary roads.

During the 1980 breeding season, we found most nests in the mid- to late-nestling stage. In 1981, eight nests were checked prior to egg-laying and three were first checked during incubation. In 1982, most nests were checked only for number of young produced; therefore 1982 data were not included in nest success estimates.

Nest success was calculated using daily sur- vival rates (Mayfield 1975), with confidence intervals developed by Johnson (1979). To calculate survival probabilities for incubation and nestling periods, we used estimates of 38 and 61 days, respectively (Griffin 1985). Young hawks were recorded as fledging successfully only if they were observed after leaving the nest.

Activities at five nests were monitored for 696 $\mathrm{hr}$ from blinds in 1980 and 1981; all nests except the nest at Puu O'O Ranch in 1981 (35 hr) were watched for more than $120 \mathrm{hr}$, with observations spaced evenly throughout the breeding season. Three nests were monitored in each of the breeding seasons, whereas one nest, Puu O'O, was observed in both years. Observations of nesting activities were made from tree and ground blinds with a spotting scope $(15-60 \times)$. Blinds were located 10-30 m from nests. We attempted to watch each nest the equivalent of 1 day per week for 8-10 weeks. In 1980, we observed nests in consecutive half-day sessions (i.e., an afternoon and the morning the next day, 6-7 hr per session), whereas in 1981 each nest was observed an entire day each week from 05:30 to 19:00 with three observers rotating duties every $4.5 \mathrm{hr}$. We attempted to identify prey items to species when possible. However, we were unable to distinguish the three potential rats (Rattus spp.), and prey was sometimes brought to the nest partially consumed making identification difficult. Terminology used to describe courtship behavior followed Brown and Amadon (1968).

To monitor hawk behavior, we captured 37 hawks (17 adults, 13 immatures, and 7 juveniles) with bal-chatri traps baited with black rats (Rattus rattus) and $3.6 \mathrm{~kg}$-test monofilament nooses (Berger and Mueller 1959). All captured birds were banded with U.S. Fish and Wildlife Service metal bands and individually colorbanded with 1-3 numbered plastic bands (National Band and Tag Co., Newport, Kentucky). Young were banded 3-4 weeks after hatching to minimize disturbance.

We radio-tagged three juveniles from three territories in August 1980 to monitor dispersal. Tail-mounted tags $(9 \mathrm{~g})$ were sutured to a single rectrix. Receivers (AVM Instrument Co., Champaign, Illinois) were used with a 4-element, yagi null-peak antenna system mounted in a vehicle. Transmitters operated in the $150-151 \mathrm{MHz}$ band and each was identifiable with a unique frequency. We attempted to monitor each radio-tagged bird for at least $8 \mathrm{hr}$ per week, with observation 
periods evenly distributed throughout daylight hours. All radio-tagged birds occurred in areas with well-developed road systems, so we could track hawks from a vehicle. In addition, observers were often able to confirm locations by visual sightings.

For all measurements, we present $\bar{x} \pm \mathrm{SE}$. We used a Mann-Whitney $U$-test to compare variation in breeding chronology between years and as a function of territory elevation, and the loglikelihood ratio test ( $G$-test) to determine what affect prior nest success had on the a bird's decision whether or not to breed in subsequent years. All statistical analyses were completed using SAS (1990). Alpha levels of 0.05 were considered significant.

\section{RESULTS}

\section{COURTSHIP AND TERRITORIAL DISPLAYS}

Aerial displays were recorded in all months except August and October, and most frequently prior to the breeding season in April (27\%) and May $(23 \%)(n=26)$. Males typically performed aerial displays more intensely than females, although females often participated $(n=17)$. Pairs performed mutual soaring, diving, and foottouching. Undulating displays sometimes followed mutual soaring displays. Both males and females performed undulating displays, both in unison $(n=2)$ and while solitary $(n=5)$. Males also performed steep downward plunges for 10$30 \mathrm{~m}(n=11)$, which Brown and Amadon (1968) referred to as the "Pot-hooks Display."

\section{NEST BUILDING AND MAINTENANCE}

Nest building was initiated at least two months before egg laying, and adults continued to add nest material during the nestling period. Our earliest record of nest building occurred on 24 January. Both sexes frequently added materials to old nest structures, and sometimes to more than one nest within the same territory. During the first 3-4 weeks of the nestling period, females often added green-leafed twigs to the nest cup $(n=39)$.

\section{NEST SITE HABITAT CHARACTERISTICS}

Twenty-eight nests were found at elevations from $30-1,740 \mathrm{~m}$ in six tree species: 17 nests in Ohia, 5 in lama (Diospyros ferra), 3 in koa, and 1 each in ironwood (Casuarian spp.), mehame (Antidesma platyphylla), and eucalyptus (Eucalyptus robusta). Nest trees were 10-24 $\mathrm{m}$ in
TABLE 1. Physical characteristics of Hawaiian Hawk nests on island of Hawaii.

\begin{tabular}{lc}
\hline \hline \multicolumn{1}{c}{ Variable } & \multicolumn{1}{c}{$\bar{x} \pm$ SE $(n)$} \\
\hline Nest height $(\mathrm{m})$ & $9.3 \pm 0.8(23)$ \\
Nest tree height $(\mathrm{m})$ & $15.8 \pm 0.9(23)$ \\
Nest tree dbh $(\mathrm{cm})$ & $50.3 \pm 6.4(23)$ \\
Nest diameter $(\mathrm{cm})$ & $64.7 \pm 2.9(21)$ \\
Nest depth $(\mathrm{cm})$ & $31.5 \pm 4.0(20)$ \\
Nest cup diameter $(\mathrm{cm})$ & $23.9 \pm 1.7(9)$ \\
Nest cup depth $(\mathrm{cm})$ & $4.2 \pm 0.6(9)$ \\
\hline
\end{tabular}

height, and nests were $3.5-18 \mathrm{~m}$ above the ground (Table 1). Most nest trees were fairly large, averaging $50 \mathrm{~cm}$ diameter at breast height (dbh), but some were as small as $10.2 \mathrm{~cm}$ dbh. Hawaiian Hawks apparently preferred stable platforms to construct nests; nine nests were placed on top of bird's-nest ferns (Asplenium ni$d u s$ ), five in trunk crotches, three on large to medium-sized branches $(20-50 \mathrm{~cm}$ diameter), and four on small branches $(<20 \mathrm{~cm}$ diameter) at their juncture with the trunk. Fifteen nests were in native ohia or ohia/koa forests, 8 in forests dominated by introduced trees, and 5 were in pastures.

Nests appeared to be used for several years, with nesting material added each breeding season. Nests averaged over $0.6 \mathrm{~m}$ diameter and 0.3 $\mathrm{m}$ deep (Table 1). All nests contained nest cups that were lined with green leaves.

\section{NESTING CHRONOLOGY AND FREQUENCY OF BREEDING}

Egg laying occurred from March to June and peaked in late April to early May $(n=20$ clutches, Fig. 1). There was no difference between laying dates in 1980 and $1981\left(U_{12,8}=\right.$ $54, P>0.05)$, or between low- $(<1,500 \mathrm{~m})$ and mid-elevation $(>1,500 \mathrm{~m})$ territories $\left(U_{4,4}=11\right.$, $P>0.05)$. Hatching occurred from May to July and peaked from late May to late June, and fledging took place from early July to mid-September, peaking in mid-August (Fig. 1).

Although breeding territories were occupied every breeding season, pairs did not attempt to nest every year. Of six territories that were followed during three breeding seasons, two pairs laid eggs at the same site all three years; three pairs apparently did not attempt to nest in one year; and one pair nested in only 1980 . Another eight pairs were tracked for two breeding seasons, of which three pairs attempted to nest both 


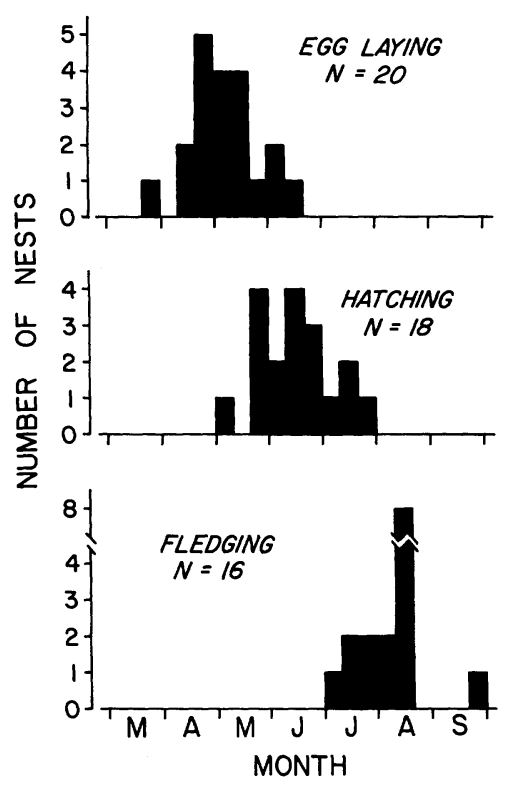

FIGURE 1. Breeding chronology of the Hawaiian Hawk on the island of Hawaii.

years, and five pairs attempted to nest in only one year. Nest success the previous breeding season did not affect the probability that hawks would re-nest at the same site $\left(G_{1}=1.3, P>\right.$ 0.20 ).

\section{MATE SELECTION}

Hawaiian Hawks have both light and dark color morphs. Of 41 pairs we observed, 8 were darkdark pairs, 11 were light-light pairs, and 22 were light-dark pairs. There was no evidence of assortative mating with respect to color morph. Assuming random pairings with respect to color morph, we expected 8.7 dark-dark pairs, 11.9 light-light pairs, and 20.4 light-dark pairs, which did not differ from our observations $\left(G_{2}=0.1\right.$, $P=0.9$ ). Frequencies of dark and light offspring resulting from different color morph pairings by adults strongly suggest that the dark morph is produced by a dominant allele for melanism that is not sex linked (Table 2).

\section{CLUTCH SIZE AND EGG CHARACTERISTICS}

There was no indication that clutch size was more than one egg during our study. Clutch size was always one for nests we found during the incubation period $(n=10)$. Of all 30 nesting attempts recorded during the 3 nesting seasons, we never saw more than one chick in a nest. A
TABLE 2. Number of light and dark morph nestlings produced by Hawaiian Hawk parents of known color morph.

\begin{tabular}{cccccc}
\hline \hline & Adult color morph & & & \\
\cline { 1 - 2 } \cline { 5 - 6 } Male & Female & $\begin{array}{c}\text { Number } \\
\text { of pairs }\end{array}$ & & Lumber of nestlings \\
\hline Light & Light & 6 & & Dark \\
Light & Dark & 5 & & 2 & 3 \\
Dark & Light & 7 & & 0 & 7 \\
Dark & Dark & 1 & & 0 & 1 \\
\hline
\end{tabular}

broken egg was found below a nest containing a single egg, but the latter may have been a replacement egg, rather than a two-egg clutch.

Mean egg size was $57.0 \pm 2.7 \times 44.0 \pm 1.2$ $\mathrm{mm}(n=9)$, and weighed $56.0 \pm 5.7 \mathrm{~g}(n=5)$ for 3-4-week-old eggs. This weight may be slightly lower than newly laid eggs (e.g., a 3day-old egg weighed $61.9 \mathrm{~g}$; L. Yoshina, pers. comm.).

Eggs were abandoned at four nests from 1980-1982, but birds re-nested at only one of these. In this territory, the female laid a replacement clutch within 24 days at an alternative nest site following nest abandonment. This pair left the original nest because a logging operation cleared much of the habitat in the area. No renesting was detected at two nests where chicks $\leq 3$ weeks old died after falling from the nest. Replacement clutches by two captive hawk pairs were laid 20 days and 26 days after their first 1egg clutches were collected for artificial incubation (L. Yoshina, pers. comm.).

\section{INCUBATION, NESTLING, AND POST-FLEDGLING PERIODS}

Incubation lasted approximately 38 days $(n=3$ nests); this estimate was imprecise because exact laying dates were uncertain. Their nestling period, the time from hatching to leaving the nest, was 59-63 days in duration ( $n=10$ nests). Adults were observed delivering prey to juveniles for 25-37 weeks after fledging $(\bar{x}=30.3$ weeks, $n=4)$.

The minimum period before juveniles dispersed from their natal territories ranged from 29 to 76 weeks $(\bar{x}=55.3 \pm 10.9$ weeks, $n=$ 4). We were able to radio-track two juveniles from late August 1980 to early June 1981, and a third juvenile from 25 August to 23 October 1980 and from 27 February to 16 March 1981. All radio-tagged juveniles remained very close 


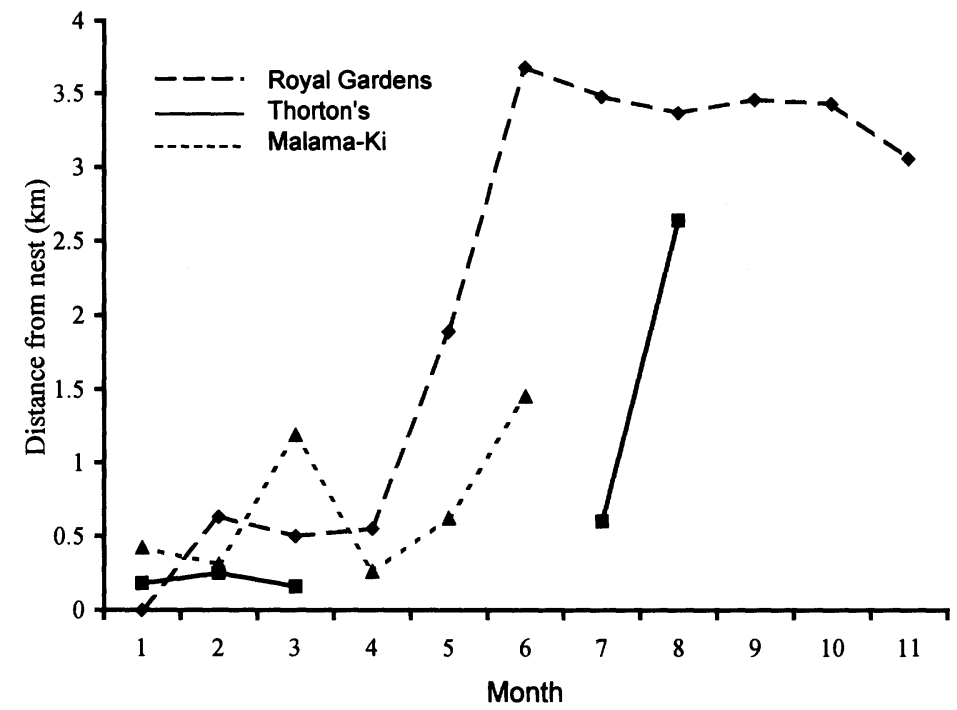

FIGURE 2. Dispersal distances of three radio-tagged, juvenile Hawaiian Hawks in the months following fledging.

to natal areas during the first two months after fledging; none moved farther than $0.63 \mathrm{~km}$ from the nest (Fig. 2). By the third month and fifth month after fledging at the Malama-Ki and Royal Gardens nests, respectively, the juveniles were ranging widely within the territories of their parents. Both of these juveniles dispersed out of their parents' territories in the sixth month after fledging. Although the juvenile female at Royal Gardens moved as far as $3.7 \mathrm{~km}$ from her natal area 6 months after fledging, she was continually resighted back at the nest begging for food for 11 months after fledging. In contrast, the male juvenile from Malama-Ki dispersed about $2 \mathrm{~km}$ from his natal area 6 months after fledging and did not return to his natal area during the subsequent 4 months that we tracked him.

\section{NEST SUCCESS}

There was no difference in hatching success between 1980 and 1981 (two-tailed $z$-test $=0.39$, $P=0.70$ ). Daily survival estimates for eggs in the incubation period were $0.991 \pm 0.009$ in 1980 and $0.986 \pm 0.009$ in 1981. Similarly, there was no difference between 1980 and 1981 in fledging success estimates $(z=0.71, P=$ 0.48 ). Nestling daily survival rates were 0.989 \pm 0.008 in 1980 and $0.995 \pm 0.004$ in 1981 .

In order to examine whether avian malaria affected chick survival, we compared nest success in territories in habitat too high to have mosquitoes (Culex quinquefasciatus) (16 of 23 nest attempts at mid-elevation [1,690 to $1,740 \mathrm{~m}]$ were successful) compared to territories that potentially had large numbers of mosquitoes (4 of 7 low elevation [ 70 to $402 \mathrm{~m}$ ] nest attempts were successful), and found no difference $\left(G_{1}=0.31\right.$, $P=0.55)$. In addition, we found no difference in nest success of hawks with territories in native forests (10 of 13 attempts were successful) compared to sites dominated by exotic, introduced vegetation (11 of 17 attempts were successful; $G_{1}=0.51, P=0.47$ ).

Forty percent of observed nest failures occurred when adults abandoned eggs $(n=10)$. Three of these abandoned eggs contained embryos at advanced stages of development, so reasons for their abandonment are unclear. However, one egg was infertile. Four other nest failures occurred when 2-3-week-old chicks fell from nests.

\section{TERRITORY AND MATE FIDELITY}

Six of eight hawk territories were monitored closely during both the 1980 and 1981 breeding seasons to determine territory and mate fidelity. At five of these six territories, adult hawks paired with the same mate and occupied the same territory in both years. The female at the sixth nest occupied the same territory, but paired 
with a different male in each of the two breeding seasons.

\section{ADULT NEST ATTENTIVENESS AND FEEDING OF YOUNG}

Eggs were incubated about $98 \%$ of the time during the incubation stage. Females usually conducted most of the incubation duties, but males sometimes assisted. The male at the Keauhou nest incubated $50-77 \%$ of the time. However, males rarely incubated in the week before hatching.

During incubation, exchanges occurred without inter-sexual aggression. Males with prey initiated the changeover by either calling from a perch within sight of the nest or perching on the nest itself. Females usually took the prey and flew away from the nest to feed. Once the female left the nest, the male typically initiated incubation and remained on the nest until the female returned.

Once eggs hatched, most males did not brood nestlings and their visits were limited to food deliveries. Females spent $92 \%$ of their time brooding during the first week after hatching. By the second week, females brooded much less (33\% of the time), and brooding activity greatly declined thereafter. After the second week posthatching, female attendance was increasingly restricted to feeding chicks and shielding them from rain showers. Chicks were protected from rain and brooded overnight through the fourth week. Although females left chicks unattended while they hunted during weeks $2-5$, they typically remained within sight of nests during this period. At week 5 , females began providing increasingly greater amounts of prey at nests, leaving young unattended for several hours at a time. By week 7, young were left unattended $97 \%$ of the time.

During the nestling period, prey exchanges between adults always occurred at the nest. If the female was not on the nest when the male arrived, she flew immediately to it to take the prey from the male with her bill or talons. Early in the nestling period (weeks 1-2) both adults often gave soft chirp calls after prey exchanges, with the male usually remaining for $15-60 \mathrm{sec}$. If he remained at the nest much longer or perched within sight of the female, she would give an aggressive tchew call until he left. As the nestling period progressed, females appeared increasingly aggressive towards males in the vi- cinity of nests. Females generally did not begin feeding chicks until males left the nest areas. Food caching by females was observed twice.

\section{NESTLING DIET}

We observed 415 prey items being fed to nestlings, of which we were able to identify $72.2 \%$. Birds (45\%) and mammals (54\%) accounted for most identified prey taken to nestlings $(n=300$ prey). Adults brought in 13 species of birds, at least 3 species of mammals, and 1 invertebrate: 1 Chukar (Alectoris chukar), 2 Japanese Quail (Coturnix japonica), 2 Wild Turkey (Melegris gallapavo) chicks, 1 Pacific Golden Plover (Pluvialis fulva), 4 Spotted Doves (Streptopelia chinesis), 1 Eurasian Skylark (Alauda arvensis), 3 Melodious Laughing-Thrush (Garrulax canorus), 24 Common Mynah (Acridotheres tristis), 49 Japanese White-eye (Zosterops japonicus), 2 Northern Cardinal (Cardinalis cardinalis), 10 House Finch (Carpodacus mexicanus), 1 Hawaii Amakihi (Hemignathus virens), 3 Apapane (Himatione singuinea), 32 unidentified birds, 87 rats (Rattus spp.), 66 house mice (Mus musculus), 5 small Indian mongoose (Herpestes auropunctatus), 4 unidentified mammals, and 3 cockroaches (Blattodea). Interestingly, their diet was dominated by introduced species, with only three native species of birds observed (Pacific Golden Plover, Hawaii Amakihi, and Apapane).

\section{DISCUSSION}

The parental care period for the Hawaiian Hawk is among the longest recorded for a buteonine species (Newton 1979). It rivals those of some tropical eagles whose weight is more than seven times greater than an adult Hawaiian Hawk (Mader 1982). Among 11 species of temperate buteos, incubation averages 33.7 days in duration, fledging takes 43.3 days, and fledged young receive parental care for 5-12 weeks (data from Newton 1979). In contrast, tropical buteos take much longer to rear their young (incubation = 35.5 days, fledging $=49.1$ days, and the parental care period after fledging lasts 8-28 weeks; Newton 1979, Santana C. and Temple 1988). The incubation period of the Hawaiian Hawk (38 days) is similar to that of other tropical buteos, but the nestling period (61 days) and parental care period following fledging (25-37 weeks) are longer than those reported for any other buteos (Newton 1979), with the possible exception of the White-tailed Hawk (B. albicau- 
datus) (Mader 1981, 1982). This long parental care period may be due in part to their dependence on avian prey, which are difficult to capture. Hawaiian Hawks evolved in an environment where only avian prey were available because mammals were introduced by humans to the islands, starting 1500 years ago (Berger 1981). The parental care period of two other tropical raptors that depend on avian prey, the Puerto Rican Sharp-shinned Hawk (Accipiter striatus venator) and Red-tailed Hawk (Buteo jamaicensis), also is significantly longer than that of temperate-zone conspecifics (Delannoy and Cruz 1988, Santana C. and Temple 1988).

The apparent year-round residency of Hawaiian Hawks on territories is conducive to longterm pair bonds. Pair fidelity appears to be high among Hawaiian Hawks, 5 of $6(83 \%)$ pairs were intact after one year, and similar to other tropical birds of prey. For example, in Savanna Hawk (Buteogallus meridionalis) populations, $64 \%$ of pairs were intact after a year $(n=11)$ (Mader 1982). In Hawaii, there is probably little opportunity to choose a new territory or new mate. Vacancies in breeding territories probably occur infrequently, and the necessary strategy for a newcomer would be to establish itself in a territory quickly after the death of an owner. Thus, a successful bird would simultaneously acquire both a territory and mate (Newton 1979). Insular Galapagos Hawks (Buteo galapagoensis) have a similar strategy; they remain in their territories for life (Faaborg 1986), as do resident Savanna Hawks in Venezuela (Mader 1982).

In many African raptors, pairs breed only 2 out of 3 years because there is a tendency for pairs which successfully breed to not nest the next year (Brown 1970). Hawaiian Hawks exhibit a similar breeding strategy, given that only $61.5 \%$ of pairs that nested successfully attempted to nest the subsequent year $(n=13)$. The extended postfledging juvenile dependency may promote this sporadic breeding cycle. Interestingly, pairs with unsuccessful nesting attempts also had a low probability $(33 \%, n=6)$ of attempting to nest in the same territory the subsequent year, which suggests a relationship to territory quality. Newton (1979) reported that territory fidelity was greatest for female European Sparrowhawks (Accipiter nisus) in habitats rich in food, but they often changed territories in habitats poor in food.
In 22 historical records of Hawaiian Hawk clutch size or numbers of young in nests from 1888 through 1979,13 nests contained 1 egg or young, 5 nests had 2 young, 3 nests had 3 young, and 1 nest contained "multiple" young (see Griffin 1985 for summary of these records). The discrepancy between frequencies of multiple young present in historic records $(41 \%)$ and our study $(0 \%, n=30)$ is significant $\left(G_{1}=18.1\right.$, $P<0.001$ ), although the reasons for this difference are unknown. One possible explanation is that prey was more abundant historically, which may have promoted larger clutch sizes (Newton 1979).

Re-nesting after loss of eggs or hatched young is common among accipiters and falcons. However, re-nesting is rare among hawks and eagles (Newton 1979), except for Harris' Hawk (Parabuteo unicinctus) and the Savanna Hawk in Venezuela (Mader 1982). Re-nesting also was rare among Hawaiian Hawks; so it does not appear to be a universal adaptation of tropical hawks.

We found no evidence of assortative mating among the polymorphic Hawaiian Hawk, in contrast to Dunkle's (1977) research with Swainson's Hawks (Buteo swainsoni). However, Schmutz and Schmutz (1981) documented random mating with respect to color morph among Ferruginous Hawks (Buteo regalis); they also suggested that one gene determines color morph. Both color morphs of the Hawaiian Hawk are widespread across the island (Scott et al. 1986).

This study was the first attempt to quantify the breeding ecology and behavior of the endangered Hawaiian Hawk. It is therefore important to discuss factors that may be affecting the species' population viability. Breeding and foraging success differs between habitats for many raptors (Newton 1979, Preston 1990). We found no relationship between nest success and habitat, although we made only limited observation of hawks breeding in undisturbed native habitats. Much of the lowland agricultural areas on the island of Hawaii are now unsuitable for Hawaiian Hawks (Griffin 1985, Scott et al. 1986), which only nest in trees. Hence, the extensive sugarcane fields and pastures found on the island have limited value because of the absence of trees. Extensive clearing of lowland forests by Polynesian and European immigrants (Kirch 1982), especially for agriculture, has reduced the 
quantity of nesting habitat available to hawks in Hawaii's forests.

Endemic passerines of Hawaii are vulnerable to avian malaria (Plasmodium relictum capistranoae), whose vector is the introduced mosquito (Culex quinquefasciatus; Warner 1968, van Riper and van Riper 1985, van Riper et al. 1986). Populations of Culex are lower above $1,500 \mathrm{~m}$ than at lower elevations, and there is a lower incidence of malaria in bird populations above $1,500 \mathrm{~m}$. Although young birds are not preferentially infected with malaria, they often do have much higher parasite levels and suffer higher mortality than adults (van Riper et al. 1986). Griffin (1985) analyzed 75 blood samples taken from 32 Hawaiian Hawks and no hematozoa were found, indicating the species has very high immunogenetic capabilities for avian malaria (C. van Riper, pers. comm.).

Avian pox, caused by strains of Poxvirus avium, also has been suspected as a factor in declines of native Hawaiian birds (Warner 1968, van Riper and van Riper 1985, Jenkins et al. 1989). This virus is transmitted directly by contact with an infected organism, or via a vector such as a mosquito (Cavill 1982). Van Riper and van Riper (1985) diagnosed pox virus in poxlike lesions in nine species of native and introduced Hawaiian passerines. Griffin (1985) observed pox-like lesions on 2 of 43 captured Hawaiian Hawks; however, no bacteriological or virological samples were collected, and hence these lesions were not confirmed as avian pox.

Although organochlorine compounds have had devastating effects on raptor populations in many parts of the world, there is limited use of these compounds in Hawaii. None or only trace amounts of organochlorine compounds were found in one Hawaiian Hawk egg collected in 1969, and three Hawaiian Hawk eggs and one chick carcass collected during 1980-1981 (Griffin 1985).

Potential for secondary poisoning of Hawaiian Hawks by rodenticides in Hawaii is believed to be low. Fumarin and zinc phosphide were the primary rodenticides used in Hawaii (D. P. Fellows, pers. comm.). There is no direct evidence of secondary poisoning of Hawaiian Hawks from these rodenticides, which are used in Hawaiian macadamia nut orchards and sugarcane fields. Effects of anticoagulants on raptors in the field remain to be assessed; however, no abnormalities occurred in Barn Owls (Tyto alba) ex- perimentally fed rats killed with fumarin (Mendenhall and Pank 1980).

Several potential predators of Hawaiian Hawks or their eggs have been introduced to Hawaii, including the domestic cat (Felis catus), Polynesian rat (Rattus exulans), black rat, Norway rat ( $R$. norvegicus), and small Indian mongoose (Scott et al. 1986). Although several of these species are known to prey on small native forest birds or seabirds in Hawaii (Berger 1981), there is no evidence that they are adversely affecting the Hawaiian Hawk population. In fact, Hawaiian Hawks now prey on many of these introduced predators.

The Hawaiian Hawk's population appears to be in a more secure position than previously thought. They are widely distributed over the island, occurring in a broad array of habitat types ranging from macadamia orchards to all types of forests on the island (Griffin 1985, Scott et al. 1986, Hall et al. 1997). They are absent only from areas that lack trees (Scott et al. 1986). The species has relatively high breeding success, in part because of the prevalence of introduced birds and mammals in the hawk's diet. In contrast to many native birds on the island, the hawk is widely distributed in low elevation habitats where avian malaria adversely affects most species. In addition, there is an absence of environmental contaminants overtly affecting the Hawaiian Hawk. Current population estimates range from 1,600 (Hall et al. 1997) to 2,700 hawks (Griffin 1989) residing on the island of Hawaii. This population estimate, coupled with the information presented in this study, indicates that reclassification from endangered to threatened status may be warranted (see also Scott et al. 1986, Hall et al. 1997). However, continued monitoring and the implementation of conservation measures to insure the existence of $\mathrm{Ha}$ waiian Hawk nesting and foraging habitat should be pursued before de-listing is considered.

\section{ACKNOWLEDGMENTS}

We are grateful to all who assisted or collaborated on this project: J. M. Scott, L. F. Pank, and D. P. Fellows, formerly of the U.S. Fish and Wildlife Service; C. J. Ralph, U.S. Forest Service (USFS); and C. van Riper, formerly of the National Park Service. T. A. Burr and M. Morin, formerly of Hawaii Department of Land and Natural Resources, arranged for study permits. Staff of Hawaii Volcanoes National Park, especially D. Ames and F. Kualani, arranged for housing and materials. L. 
Pau and F. C. Parks assisted in equipment construction. R. Banashek, former Young Adult Conservation Corps Director, provided volunteer field assistants. The Patuxent Wildlife Research Center and National Fish and Wildlife Health Laboratory provided chemical analyses and necropsy reports on a carcass and eggs collected in Hawaii. J. D. Jacobi, U.S. Geological Survey, Biological Resources Division, Hawaii Field Researcl Station provided valuable assistance in vegetation analyses around hawk nests, L. H. Yoshina (Director, Panaewa Zoo, Hilo, Hawaii) provided information on captive Hawaiian Hawks, and J. A. Baldwin (USFS) assisted with statistical analysis of data. S. J. Doyle assisted with field research during 1981-1982. D. G. Newman provided editorial assistance, and S. S. Clark gave technical and secretarial support. This publication is a contribution from the Missouri Cooperative Fish and Wildlife Research Unit and the Missouri Agricultural Experiment Station.

\section{LITERATURE CITED}

Armstrong, R. W. 1973. Atlas of Hawaii. Univ. Press of Hawaii, Honolulu.

BALDING, T., AND E. DibBle. 1984. Responses of Redtailed, Red-shouldered, and Broad-winged Hawks to high volume playback recordings. Passenger Pigeon 46:71-75.

BANKo, W. E. 1980. History of endemic Hawaiian birds. Part I. Population histories-species accounts. Forest birds: Hawaiian Hawk ('Io). CPSU/ UH Avian History Rep. 6A, Dept. Botany, Univ. Hawaii, Honolulu.

Berger, A. J. 1981. Hawaiian birdlife. Univ. Press of Hawaii, Honolulu.

Berger, D. D., AND H. C. Mueller. 1959. The balchatri: a trap for birds of prey. Bird-Banding 30 : 18-26.

Brown, L. H. 1970. Some factors affecting breeding in eagles. Ostrich 8:157-167.

Brown, L. H., AND D. Amadon. 1968. Eagles, hawks, and falcons of the world. Country Life Books, London.

Cavill, J. P. 1982. Viral diseases, p. 515-527. In N. Petrak [ed.], Diseases of cage and aviary birds. Lea and Febiger, Philadelphia, PA.

Delannoy, C. A., AND A. CRUZ. 1988. Breeding biology of the Puerto Rican Sharp-shinned Hawk (Accipiter striatus venator). Auk 105:649-662.

DUNKLE, S. W. 1977. Swainson's Hawk on the Laramie Plains, Wyoming. Auk 94:65-71.

FAABORG, J. T. 1986. Reproductive success and survivorship of the Galapagos Hawk Buteo galapagoensis: potential costs and benefits of cooperative polyandry. Ibis $128: 337-347$.

GrIFFIN, C. R. 1985. Biology of the Hawaiian Hawk Buteo solitarius. Ph.D. diss., Univ. Missouri, Columbia, MO.

GRIFFIN, C. R. 1989. Status and conservation of raptors in the Hawaiian Islands, p. 155-160. In B. G. Pendleton [ed.], Proc. Western Raptor Manage. Symp., Natl. Wildl. Fed., Washington, DC.

Hall, L. S., M. L. Morrison, AND P. H. BloOM. 1997.
Population status of the endangered Hawaiian Hawk. J. Raptor Res. 31:11-15.

Jenkins, C. D., S. A. Temple, C. Van Riper III, AND W. HANSEN. 1989. Disease-related aspects of conserving the endangered Hawaiian Crow, p. 77-87. In J. E. Cooper [ed.], Disease and threatened birds. Int. Council Bird Preserv. Tech. Publ. 10.

JoHnson, D. H. 1979. Estimating nest success: the Mayfield method and an alternative. Auk 96:651661.

KIRCH, P. V. 1982. The impact of prehistoric Polynesians on the Hawaiian ecosystem. Pac. Sci. 36:114.

MADER, W. J. 1981. Notes on nesting raptors in the llanos of Venezuela. Condor 83:48-51.

MADER, W. J. 1982. Ecology and breeding habits of the Savanna Hawk in the llanos of Venezuela. Condor 84:261-271.

MAYFIELD, H. F. 1975. Suggestions for calculating nest success. Wilson Bull. 87:456-466.

Mendenhall, V. M., AND L. F. Pank. 1980. Secondary poisoning of owls by anticoagulant rodenticides. Wildl. Soc. Bull. 8:311-315.

Newton, I. 1979. Population ecology of raptors. Buteo Books, Vermillion, SD.

Olson, S. L. 1990. The supposed California record of a Hawaiian Hawk, Buteo solitarius. 'Elepaio 50: $1-2$.

Olson, S. L., AND H. F. JAmeS. 1997. Prehistoric status and distribution of the Hawaiian Hawk (Buteo solitarius), with the first fossil record from Kauai. Bishop Mus. Occ. Papers 49:65-69.

Paton, P. W. C, F. J. Messina, and C. R. Griffin. 1994. A phylogenetic approach to reversed size dimorphism in diurnal raptors. Oikos 71:492-498.

PRESTON, C. R. 1990. Distribution of raptor foraging in relation to prey biomass and habitat structure. Condor 92:107-112.

Santana C. E., and S. A. Temple. 1988. Breeding biology and diet of Red-tailed Hawks in Puerto Rico. Biotropica 20:151-160.

SAS INSTITUTE INC. 1990. SAS/STAT user's guide. Version 6, 4th ed. SAS Institute, Inc., Cary, NC.

SchmuTz, S. M., AND J. K. SchmUTZ. 1981. Inheritance of color phases on Ferruginous Hawks. Condor 83:187-189.

SCOTT, J. M., S. MountainsPRING, F. L. Ramsey, AND C. B. KEPLER. 1986. Forest bird communities of the Hawaiian Islands: their dynamics, ecology, and conservation. Stud. Avian Biol. 9:1-431.

VAN RIPER, S. G., AND C. VAN RIPER III. 1985. A summary of known parasites and diseases recorded from the avifauna of the Hawaiian Islands, p. 298371. In C. P. Stone and J. M. Scott [eds.], Hawaii's terrestrial ecosystems: preservation and management. Univ. Hawaii Press, Honolulu.

VAN RIPER, C., III, S. G. VAN RIPER, M. L. GOFF, AND M. LAIRD. 1986. The epizootiology and ecological significance of malaria in Hawaiian land birds. Ecol. Monogr. 56:327-344.

WARNER, R. E. 1968. The role of introduced diseases in the extinction of the endemic Hawaiian avifauna. Condor 70:101-120. 